Sensors 2003, 3, 276-284

sensors

ISSN 1424-8220

(C) 2003 by MDPI

http://www.mdpi.net/sensors

Review

\title{
Measurement of Nitric Oxide Production in Biological Systems by Using Griess Reaction Assay
}

\author{
Jie Sun*, Xueji Zhang, Mark Broderick and Harry Fein \\ World Precision Instruments, Inc, Sarasota International Trade Center, 175 Sarasota Center Boulevard, \\ Sarasota, FL 34240, USA. Tel. (941) 371-1003, Fax (941) 377-5428, e-mail jie@wpiinc.com \\ * Author to whom correspondence should be addressed.
}

Received: 27 February 2003 / Accepted: 11 March 2003 / Published: 22 August 2003

\begin{abstract}
A review of using Griess Reaction method to determine nitric oxide production in biological systems.

Keywords: Griess Reaction, nitric oxide, NO, nitric oxide synthase, NOS, nitrite, nitrate, cadmium, nitrate reductase.
\end{abstract}

\section{Introduction}

Nitric oxide (NO) plays essential roles in mammalian life [1,2]. Synthesis of this seemingly most simple molecule involves one of the most complicated enzymes in nature, the nitric oxide synthase (NOS), which contains several cofactors and is highly regulated [3]. Multiple physiological and pathophysiological functions of nitric oxide are achieved by using diverse classes of NOS (neuronal NOS, endothelial NOS, inducible NOS and mitochondria NOS). Unregulated production of nitric oxide can cause nitrosative stress, leading to damages of proteins/DNA and to cell injury and death [4,5]. Indeed nitric oxide has shown to be involved in a number of important human diseases. Inspired by pioneering work of Furchgott, Ignarro and Murad, nitric oxide has been becoming one of the most studied molecules since last decade. Existence of nitric oxide in biology is not limited to mammalian life. Its production and its important roles have also been demonstrated in plants and bacteria [6,7].

Measurement of nitric oxide in biological systems needs careful considerations. Nitric oxide is rapidly oxidized to nitrite and/or nitrate by oxygen. The half-life of nitric oxide in biological matrix is very short, ranging from less than 1 second in the presence of hemoglobin to $~ 30$ seconds [8-10]. Nitric oxide can be measured in situ by using fast-response amperometric electrode sensors [11,12] 
and by using in-vivo trapping techniques with fluorescent or EPR-active reporter molecules [13,14]. Alternatively, integrated nitric oxide production can be estimated from determining the concentrations of nitrite and nitrate end products. The measurement of nitrate/nitrite concentration or of total nitrate and nitrite concentration (NOx) is routinely used as an index of NO production [15]. Interestingly, before endogenous NO production was realized, pioneering work of Tannenbaum and coworkers (measuring nitrate concentration in urine) established that there were excessive amount of nitrate production above dietary intake, which was further stimulated by inflammation [16]. Current understanding of nitric oxide synthesis and metabolism provides an explanation of their observation. Here we will review Griess Reaction assay technique to determine nitrite concentration in biological matrixes, and related techniques of quantitative reduction of nitrate to nitrite. Our special emphasis is on commercial bench-top assay kits.

Nitrate and/or nitrite can be quantified directly by UV absorbance measurement, GC-MS, HPLC, ion-selective electrodes and capillary electrophoresis. Due to expense, time-consuming procedures and/or limitations in sensitivity of these methods, total NOx is typically determined by converting nitrate into nitrite followed by measuring total amount of nitrite in the sample. In this widely used practice, nitrite concentration is typically measured by a number of additional well-known methods such as colorimetric Griess assay [15,17], fluorescent assays [13,18], chemiluminescence assay [19] and electrochemical detection [11]. To determine nitrate concentration specifically, the same sample is measured twice separately with and without a reducing agent. The difference of concentrations between NOx and nitrite is taken as the concentration of nitrate.

\section{Griess Reaction Assay}

Griess Reaction was first described in 1879 [20,21]. Because of its simplicity, it has been used extensively in analysis of numerous biological samples including plasma (serum), urine, CSF, saliva and cell culture media [17]. In this method, nitrite is first treated with a diazotizing reagent, e.g., sulfanilamide (SA), in acidic media to form a transient diazonium salt. This intermediate is then allowed to react with a coupling reagent, N-naphthyl-ethylenediamine (NED), to form a stable azo compound. The overall reaction is described in the scheme below. The intense purple color of the product allows nitrite assay with high sensitivity and can be used to measure nitrite concentration as low as $\sim 0.5 \mu \mathrm{M}$ level. The absorbance of this adduct at $540 \mathrm{~nm}$ is linearly proportional to the nitrite concentration in the sample.

Because of the two-step nature of the Griess Reaction, variations exist among published Griess Reaction assays. For example, SA and NED can be pre-mixed in an acid medium before reacting with nitrite. Yet in a different version, after reacting nitrite with SA in acidic medium, NED is added 10 minutes later. The most popular version seems to be the sequential method in which nitrite is mixed with SA first, followed immediately by addition of NED. This method seems to give highest yield of the chromophore, and therefore most sensitive way to perform Griess Reaction assay [22,23]. This approach is adopted in most commercial kits. 


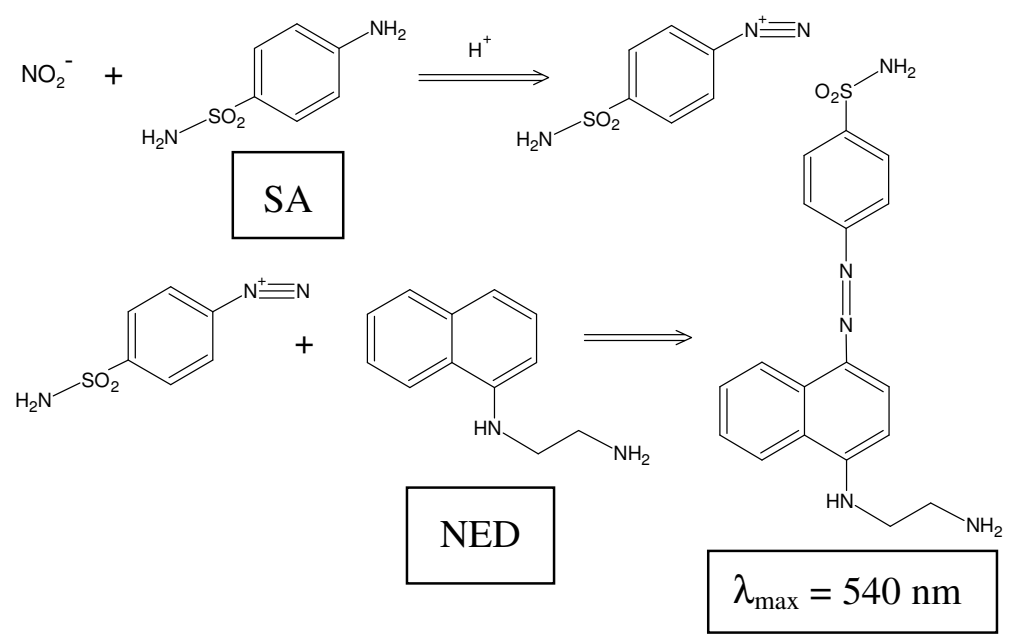

\section{Nitrate Reduction}

The reduction of nitrate to nitrite is often accomplished by treating samples with chemical reductants (e.g., cadmium, zinc and hydrazine) or bacterial nitrate reductase (NR) enzymes. Some of these methods are not reliable. For example, zinc is too reactive that it can further reduce resultant nitrite. For applications in biological samples, literature is dominated by reduction methods based on cadmium and NR enzymes [17,22-25]. Most recently, a Griess Reaction assay has been described in which $\mathrm{VCl}_{3}$ was used as a reductant [26]. This is an interesting alternative, however, instability of $\mathrm{VCl}_{3}$ solution probably requires frequent checks and limits shelf-life when provided in a reagent kit format.

Cadmium has a reduction potential of $-0.403 \mathrm{~V}$. On the other hand, redox potential of nitrate/nitrite couple is dependent on $\mathrm{pH}$ ranging from $0.94 \mathrm{~V}$ in acidic solution to $0.015 \mathrm{~V}$ in basic solution. Therefore, reduction reaction of nitrate into nitrite by cadmium is thermodynamically favorable [27]. It is also thermodynamically possible for cadmium to reduce nitrite further into lower oxidation states. However all these reduction reactions are slow due to kinetic barriers. Nitrate-to-nitrite conversion efficiency therefore depends on time of mixing, cadmium surface area/sample volume ratio, $\mathrm{pH}$ and other factors. A metallic copper layer has been shown to catalyze the reduction process of nitrate to nitrite. This copperized cadmium method is one of the most popular methods among researchers $[17,28,29]$. In this method, cadmium is exposed to $\mathrm{CuSO}_{4}$ solution, $\mathrm{Cu}^{2+}$ is reduced on the cadmium surface to form a porous metallic copper "coat". This copper layer facilitates electron transfer from cadmium to nitrate [27]. The nitrate to nitrite conversion can then be achieved rapidly using a relatively small surface area. The overall reaction in a mild alkaline solution can be described as following:

$$
\mathrm{NO}_{3}{ }^{-}+\mathrm{H}_{2} \mathrm{O}+\mathrm{Cd} \rightarrow \mathrm{NO}_{2}^{-}+\mathrm{Cd}^{2+}+2 \mathrm{OH}^{-}
$$


It takes granules cadmium pellets several hours to reduce $\sim 100$ nmoles of nitrate. In comparison, powder form of cadmium can reduce same amount of nitrate in several minutes. Copperized granules cadmium pellets can also achieve this reduction in several minutes. However, copperized powder cadmium is too reactive that reduction end product nitrite is further reduced to give an apparent low yield in Griess Reaction assay. Therefore exact experimental conditions (surface area/sample volume ratio, speed and time of mixing etc.) are crucial for quantitative nitrate reduction. One of the early papers described a successful strategy of using high-pressure cadmium column in conjunction with the automated Griess Reaction assay system in analyzing a variety of biological samples [27]. The cadmium and copperized cadmium techniques remain the choice of nitrate to nitrite reduction among many researchers. The materials with consistent quality are readily available, and remain stable for long period of time. The metal can be cleaned and reused. However, reduction efficiency seems to decline after several cycles of usage. Most recently, copper-cadmium alloy was reported to be able to reduce nitrate into nitrite within one hour [30]. One of the drawbacks of using cadmium is the toxicity associated with the metal. Commercial kits using both cadmium and copperized cadmium method are available.

Bacterial NR enzyme catalyzes the reduction of nitrate by NADPH as shown below [24]. This

$$
\mathrm{NO}_{3}{ }^{-}+\mathrm{NADPH}+\mathrm{H}^{+} \rightarrow \mathrm{NO}_{2}^{-}+\mathrm{NAPD}^{+}+\mathrm{H}_{2} \mathrm{O}
$$

method has been widely used in NOx determination in biological samples. However, it has been discovered that NADPH interferes with subsequent Griess Reaction [22]. Methods have developed to convert NADPH into $\mathrm{NADP}^{+}$by using lactate dehydrogenase (LDH) or pyruvate dehydrogenase. Verdon et al. presented evidence that both NADPH and NAPD ${ }^{+}$can interfere with Griess Reaction [22]. Their preferred method is to use the limited amount of NADPH/NAPD ${ }^{+}$and to use a second enzyme glucose-6-phosphate dehydrogenase simultaneously in the assay system to recycle NADPH. NR from plants and fungi can use NADH as the cofactor instead of NADPH [31]. However, NADH is similar to NADPH in redox properties and its quantity must be limited in the assay system. Enzymatic reduction is slightly less laborious than cadmium reduction method. Disadvantages of the enzymatic method include incomplete nitrate reduction at high concentration range and batch variations related to enzyme activity changes in different preparations and during storage [32]. Enzymes and cofactors usually need to be stored frozen separately from other reagents. Available commercial kits use both NADPH and NADH as the cofactor for NR. Some kits use LDH to decompose NADPH after nitrate reduction is complete, others use proprietary technology to decompose NADPH during nitrate reduction.

\section{Sample preparation and other considerations}

Biological samples such as plasma (serum) has a high content of protein and high turbidity. Deproteinization step is necessary in the Griess Reaction assay for such samples [15]. Because nitrite can be converted into nitric oxide and nitrogen dioxide gases under acid condition, acid protein precipitation methods promote the loss of nitrite and should be avoided at any cost for Griess Reaction assay [26]. Early works used Carrez Reagent (zinc acetate + potassium ferrocyanide), alumina cream, 
zinc sulfate $/ \mathrm{NaOH}$ and similar reagents to deproteinize samples [33]. In a strict sense, these reagents are merely clearing agents because they removes fatty material, particular substance and varying amount of proteins by occlusion. In terms of protein removal, Carrez method eliminate about $85 \%$ of protein from samples. As a comparison $\mathrm{ZnSO}_{4}$ and other earlier chemical methods remove $\sim 50 \%$ protein. However, zinc sulfate method is effective in preventing the formation of precipitate/turbidity in subsequent Griess Reaction even in samples with high protein content such as plasma. The zinc sulfate based methods are satisfactory to many researchers and are still very polular $[15,29]$. Guevara et al. reported reduced reproducibility at high nitrate concentration $(>50 \mu \mathrm{M})$ when $\mathrm{ZnSO}_{4}$ method was used in conjunction with NR/NADPH method [23]. We did not observe such a phenomenon with $\mathrm{ZnSO}_{4} /$ copperized cadmium procedures. Another widely used deproteinization method utilizes centrifuge membrane filters that retain protein, other large molecular weight molecules and particular material. The solutions passed through the membrane filter are collected and are used for Griess Reaction assay. This procedure involves washing centrifuge filters before adding samples. For plasma or serum samples, actual centrifugation typically takes $1-3$ hours. This procedure is more laborious than chemical methods, but the samples are not diluted for Griess Reaction assay. Deproteinization of biological samples can also be accomplished by using methanol/diethylether) [23].

A number of endogenous and exogenous compounds can interfere with Griess Reaction assay. These compounds include ascorbate, reduced thiols, phosphate, $\mathrm{N}^{\mathrm{G}}$-nitro-L-arginine and heparin [28,33-37]. Most of these compounds can cause interference in both enzyme-reduction and cadmiumreduction methods. Heparin has been known to interfere only in the enzyme-based assay. Methods of eliminating the interference are available $[28,33]$. For example, $\mathrm{ZnSO}_{4}$ deproteinization procedure can also reduce interference from ascorbate and phosphate [28]. When NOx concentration is sufficiently high, samples can simply be diluted to limit some interference to a negligible level. Commercial kits generally do not contain procedures to remove interfering compounds. Users are urged to study percentage of recovery when a new type of sample is assayed. This can be accomplished by adding a fixed amount of nitrate or nitrite standard to a sample and by determining the difference of the NOx concentrations with commercial kits.

Contamination of nitrate in chemicals/reagents is also of concern. For example, anticoagulants used for blood collection were shown to contain variable levels of nitrate and nitrite, depending on manufacturer [38]. Some cell culture media contain relatively high level of nitrate; observation of very small amount of NOx production in such media could be difficult. When samples contain ultra low levels of NOx are analyzed, caution should be exercised to take into consideration of contamination even in laboratory ware such as microcentrifuge tubes, disposable pipette tips and ultrafiltration membranes [38]. Dust also contains a significant level of nitrate; experiments should be performed in a relatively dust-free area with duplicate or triplicate tests.

\section{Commercially Available Griess Reaction Kits}

Because of the increased demand for the analysis of nitrate and nitrite in biological samples, more vendors made Griess Reaction assay kit available to researchers in recent years. Following table summarizes current kit providers and their main features. To date, there is no systematic study to compare the performance of Griess Reaction kits from different vendors. Basic variations are nitrate 
reduction method (Cadmium-based or enzymatic) and deproteinization procedures (chemicals or ultrafiltration). Generally, cadmium-based kit gives larger linear measurement range $(\geq 100 \mu \mathrm{M})$. Enzymatic kits typically has decreased reduction yield at $\sim 40 \mu \mathrm{M}$ or above. However, "classic" cadmium-based methods are slightly labor-intensive. Deproteinization with chemical methods is cheaper and faster. Centrifuge filtration is more expensive and more time-consuming but does not dilute samples. Depends on anticipated level of NOx and laboratory equipment, users have to decide which commercial kit is most suitable for a particular type of sample.

Table 1. Commercial Griess Reaction assay kits used for biological samples.

\begin{tabular}{|c|c|c|c|c|c|}
\hline Company & $\begin{array}{c}\text { Nitrate Reduction } \\
\text { Method }\end{array}$ & $\begin{array}{l}\text { Deproteinization } \\
\text { Method }\end{array}$ & Kit Size & Notes & Price \\
\hline $\begin{array}{l}\text { World Precision } \\
\text { Instruments, Inc }\end{array}$ & $\begin{array}{c}\text { Copperized } \\
\text { Cadmium Pellets }\end{array}$ & $\mathrm{ZnSO}_{4} / \mathrm{NaOH}$ & $\begin{array}{c}100 \text { tests } \\
(500 \text { wells })\end{array}$ & & $\$ 249$ \\
\hline $\begin{array}{l}\text { OXIS Research } \\
\text { Products, Inc }\end{array}$ & Cadmium Powder & $\mathrm{ZnSO}_{4} / \mathrm{NaOH}$ & $\begin{array}{c}100 \text { tests } \\
(500 \text { wells })\end{array}$ & & $\$ 249$ \\
\hline $\begin{array}{l}\text { Oxford Biomed. } \\
\text { Research, Inc }\end{array}$ & $\begin{array}{l}\text { Cadmium } \\
\text { Pellets }\end{array}$ & $\mathrm{ZnSO}_{4} / \mathrm{NaOH}$ & 96 wells & & $\$ 195$ \\
\hline Cayman Chemical & $\overline{\text { NR/NADPH }}$ & $\mathrm{N} / \mathrm{A}$ & $2 \times 96$ wells & $\begin{array}{l}\text { Ultrafiltration recommended for } \\
\text { plasma \& tissue homogenates }\end{array}$ & $\$ 175$ \\
\hline Cayman Chemical & $\begin{array}{l}\text { NR/NADPH } \\
+ \text { LDH }\end{array}$ & N/A & 96 wells & $\begin{array}{l}\text { Ultrafiltration recommended for } \\
\text { plasma \& tissue homogenates }\end{array}$ & $\$ 175$ \\
\hline $\begin{array}{l}\text { Roche Diagnostics } \\
\text { GmbH }\end{array}$ & NR/NADPH & N/A & 96 wells & $\begin{array}{l}\text { Ultrafiltration recommended for } \\
\text { serum, Carrez recommended for } \\
\text { urine. }\end{array}$ & $\$ 347$ \\
\hline $\begin{array}{l}\text { Roche Diagnostics } \\
\text { GmbH }\end{array}$ & NR/NADPH & N/A & 64 tests & $\begin{array}{l}\text { Carrez recommended for cell } \\
\text { culture media and other samples. }\end{array}$ & $\$ 198$ \\
\hline Active Motif & NR/NADPH & N/A & 2x96 wells & $\begin{array}{l}\text { Proprietary technology degrades } \\
\text { NADPH during reduction. }\end{array}$ & $\$ 265$ \\
\hline $\begin{array}{c}\text { Phoenix } \\
\text { Pharmaceutical }\end{array}$ & NR/NADPH & N/A & 96 wells & $\begin{array}{l}\text { Proprietary technology degrades } \\
\text { NADPH during reduction. }\end{array}$ & $\$ 180$ \\
\hline Kamiya Biomedical & NR/NADPH & N/A & 96 wells & $\begin{array}{l}\text { Proprietary technology degrades } \\
\text { NADPH during reduction. }\end{array}$ & $\$ 195$ \\
\hline BioVision & NR/NADPH & N/A & 2x96 wells & & $\$ 225$ \\
\hline $\begin{array}{l}\text { Oxford Biomed. } \\
\text { Research, Inc }\end{array}$ & NR/NADH & $\mathrm{N} / \mathrm{A}$ & 96 wells & & $\$ 195$ \\
\hline Calbiochem & NR/NADH & N/A & 96 wells & & $\$ 237$ \\
\hline $\begin{array}{l}\text { OXIS Research } \\
\text { Products, Inc }\end{array}$ & NR/NADH & N/A & 96 wells & & $\$ 390$ \\
\hline Assay Designs & NR/NADH & N/A & 96 wells & Ultrafiltration recommended & $\$ 200$ \\
\hline
\end{tabular}

\section{Conclusions}

Commercial Griess Reaction kits for the determination of total nitrate and nitrite concentration as an index of nitric oxide production in biological samples are widely available at a very reasonable cost. These kits utilize either cadmium or nitrate reductase to reduce nitrate into nitrite. Biological matrixes are complex and Griess Reaction is prone to interferences, users should assess suitability of a commercial kit for the specific type of samples on hand. Strict control and care are required to generate valid analytical data even when commercial reagent kits are used. 


\section{References and Notes}

1. Moncada, S.; Palmer, R. J. M.; Higgs, E. A. Nitric oxide: physiology, pathophysiology, and pharmacology. Pharmacol. Rev. 1991, 43, 373-376.

2. Schmidt, H. H. H. W.; Walter, U. NO at work. Cell 1994, 78, 919-925.

3. Nathan, C.; Xia, Q. Nitric oxide synthases: roles, tolls, and controls. Cell 1994, 78, 915-918.

4. Hausladen, A.; Stamler, J. S. Nitrosative stress. Methods Enzymol. 1999, 300, 389-395.

5. Murphy, M. P. Nitric oxide and cell death. Biochimica et Biophysica Acta 1999, 1411, 401-414.

6. Watmough N. J.; Butland G.; Cheesman, M. R.; Moir, J. W. B.; Richardson, D. J.; Spiro, S. Nitric oxide in bacteria: synthesis and consumption. Biochimica et Biophysica Acta 1999, 1411, 456-474.

7. Lum, H. K.; Butt, Y. K.; Lo, S. C. Hydrogen peroxide induces a rapid production of nitric oxide in mung bean (Phaseolus aureus). Nitric Oxide 2002, 6, 205-213.

8. Feldman, P. L.; Griffith, O. W.; Stuehr, D. J. The surprising life of nitric oxide. C\&EN 1993, December, 26-38.

9. Knowles, R. G; Moncada, S. Nitric oxide as a signal in blood vessels. TIBS 1992, 17, 399-402.

10. Eich. R. F.; Li, T.; Lemon, D. D.; Doherty, D. H.; Curry, S. R.; Aitken, J. F.; Mathews, A.J.; Johnson, K. A.; Smith, R. D.; Phillips, G. N. Jr; Olson, J. S. Mechanism of NO-induced oxidation of myoglobin and hemoglobin. Biochemistry 1996, 35, 6976-6983.

11. Zhang, X.; Broderick, M. Electrochemical NO sensors and their applications in biomedical research. Biomedical Significance of Nitric Oxide 2003, International Scientific literature, Inc.

12. Malinski, T.; Mesaros, S.; Patton, S. R.; Mesarosova, A. Direct measurement of nitric oxide in the cardiovascular system. Physiol. Res. 1996, 45, 279-284.

13. Kojima, H.; Nakatsubo. N.; Kikuchi, K.; Kawahara, S.; Kirino, Y.; Nagoshi, H.; Hirata, Y.; Nagano, T. Detection and imaging of nitric oxide with novel fluorescent indicators: diaminofluoresceins. Anal. Chem. 1998, 70, 2446-2453.

14. Kleschyov, A. L.; Munzel, T. Advanced spin trapping of vascular nitric oxide using colloid iron diethyldithiocarbamate. Methods Enzymol. 2002, 359, 42-51.

15. Moshage, H.; Kok, B.; Huizenga, J. R.; Jansen, P. L. Nitrite and nitrate determination in plasma: a critical evaluation. Clin. Chem. 1995, 41, 892-896.

16. Wagner, D. A.; Young, V. R.; Tannenbaum, S. R.; Schultz, D. S.; Deen, W. M. Mammalian nitrate biochemistry: metabolism and endogenous synthesis. IARC Sci. Publ. 1984, 57, 247-253.

17. Green, L. C.; Wagner, D. A.; Glogowski, J.; Skipper, P. L.; Wishnok, J. S.; Tannenbaum, S. R. Analysis of nitrate, nitrite, and $\left[{ }^{15} \mathrm{~N}\right]$ nitrate in biological samples. Anal. Biochem. 1982, 126, 131138.

18. Casey, T.E.; Hilderman, R. H. Modification of the cadmium reduction assay for detection of nitrite production using fluorescence indicator 2,3-diaminonaphthalene. Nitric Oxide 2000, 4, 6774.

19. Yang, F.; Troncy, E.; Francoeur, M.; Vinet, B.; Vinay, P.; Czaika, G.; Blaise, G. Effect of reducing agents and temperatures on conversion of nitrite and nitrate to nitric oxide and detection of NO by chemiluminescence. Clin. Chem. 1997, 43, 657-662.

20. Griess, P. Ber. Deutsch Chem. Ges. 1879, 12, 426. 
21. Shinn, M. B. Ind. Engng. Chem. Analyt. Edn. 1941, 13, 33.

22. Verdon, C. P.; Burton, B. A.; Prior, R. L. Sample pretreatment with nitrate reductase and glucose-6-phosphphate dehydrogenase quantitatively reduces nitrate while avoiding interference by $\mathrm{NADP}^{+}$when the Griess Reaction is used to assay for nitrite. Anal. Biochem. 1995, 224, 502508.

23. Guevara, I.; Iwanejko, J.; Dembinska-Kiec, A.; Pankiewicz, J.; Wanat, A.; Anna, P.; Golabek, I.; Bartus, S.; Malczewska-Malec, M.; Szczudlik A. Determination of nitrite/nitrate in human biological material by the simple Griess reaction. Clin. Chim. Acta 1998, 274, 177-188.

24. Gillam, M. B.; Sherman, M. P.; Griscavage, J. M.; Ignarro, L. J. A spectrophotometric assay for nitrate using NADPH oxidation by Aspergillus nitrate reductase. Anal. Biochem. 1993, 212, 359365.

25. Vodovotz, Y. Modified microassay for serum nitrite and nitrate. Biotechniques 1996, 20, 390394.

26. Miranda, K. M.; Espey, M. G.; Wink, D. A. A rapid simple spectrophotometric method for simultaneous detection of nitrate and nitrite. Nitric Oxide 2001, 5, 62-71.

27. Zhang, J.-Z.; Fischer, C. J.; Ortner, P. B. Comparison of open tubular cadmium reactor and packed cadmium column in automated gas-segmented continuous flow nitrate analysis. Intern. J. Environ. Anal. Chem. 2000, 76, 99-113.

28. Cortas, N.; Wakid, N. W. Determination of inorganic nitrate in serum and urine by a kinetic cadmium-reduction method. Clin. Chem. 1990, 36, 1440-1443.

29. Navarro-Gonzalvez, J. A.; Garcia-Benayas, C.; Arenas, J. Semiautomated measurement of nitrate in biological fluids. Clin. Chem. 1998, 44, 679-681.

30. Sastry, K. V.; Moudgal, R. P.; Mohan, J.; Tyagi, J. S.; Rao, G. S. Spectrophotometric determination of serum nitrite and nitrate by copper-cadmium alloy. Anal. Biochem. 2002, 306, 79-82.

31. Campbell, E. R.; Kinnunen-Skidmore, R. P.; Winowiecki, L. A.; Campbell, W. H. A new trend in nitrate analysis: an enzyme-based field test for nitrate. American Laboratory 2000, February, 9092.

32. Granger, D. L.; Hibbs, J. B. Jr.; Broadnax, L. M.; Urinary nitrate excretion in relation to murine macrophage activation: influence of dietary L-arginine and oral $\mathrm{N}^{\mathrm{G}}$-monomethyl-L-arginine. $J$. Immunol. 1991, 146, 1294-1302.

33. Usher, C. D; Telling G. M. Analysis of nitrate and nitrite in foodstuffs: a critical review. J. Sci. Fd. Agric. 1975, 2, 1793-1805.

34. Nims, R. W.; Darbyshire, J. F.; Saavedra, J. E.; Christodoulou, D.; Hanbauer, I.; Cox, G. W.; Grisham, M. B.; Laval, F.; Cook, J. A.; Krishna, M. C.; Wink, D. A. Colorimetric methods for the determination of nitric oxide concentration in neutral aqueous solutions. Methods 1995, 7, 4854.

35. Greenburg, S. S.; Xie, J.; Spitzer, J. J.; Wang, J.; Lancaster, J.; Grisham, M. B.; Powers, D. R.; Giles, T. D. Nitro containing L-arginine analogs interfere with assays for nitrate and nitrite. Life Sci. 1995, 57, 1949-1961. 
36. Nithipatikom, K.; Pratt, P. F.; Campbell, W. B. Nitro-L-arginine interferes with the cadmium reduction of nitrate/Griess reaction method of measuring nitric oxide production. Eur. J. Clin. Chem. Clin. Biochem. 1996, 34, 133-137.

37. Dembny, K. D.; Roza, A. M.; Johnson, C.; Adams, M. B.; Pieper, G. M. Heparin interferes with the determination of plasma nitric oxide by inhibition of enzymatic conversion of nitrate to nitrite by nitrate reductase. Clin. Chim. Acta 1998, 275, 107-114.

38. Ishibashi, T.; Himeno, M.; Imaizumi, N.; Maejima, K.; Nakano, S.; Uchida, K.; Yoshida, J.; Nishio, M. $\mathrm{NO}_{\mathrm{x}}$ contamination in laboratory ware and effect of countermeasures. Nitric Oxide, 2000, 4, 516-525.

Sample Availability: Available from the authors.

(C) 2003 by MDPI (http://www.mdpi.org). Reproduction is permitted for noncommercial purposes. 